\title{
'N SAMEVATTING EN KRITIESE EVALUASIE VAN B S CHILDS SE KANONIESE BENADERING
}

\author{
N A JANSE VAN RENSBURG
}

\begin{abstract}
A summary and critical evaluation of B S Childs' canonical approach

Childs is disappointed with the results of the historical critical method. He made an appeal for a totally new approach in which the relation between historical critical study of the Bible and its theological use as religious literature within the community of faith will be completely rethought. He proposes a canonical approach in which the final form of the text, not the pre- or past-canonical developments, will be normative for the community of faith. Because of Childs' enormous influence as Old Testament interpreter and the high standard of his work in the past, expectations ran high for the publication of his Old Testament Theology. In the light of his bold influence and the enormous promise of his work, Old Testament Theology in a canonical context is unfortunately a disappointment. One can only hope that he still intends writing a book that will illustrate how a theology is written in canonical context.
\end{abstract}

\section{INLEIDING}

Sedert die geboorte-uur van die vak Ou-Testamentiese Teologie met die nou reeds alombekende en beroemde toespraak van Johann Philip Gabler in 1787 is die geskiedenis van die vak gekenmerk deur onsekerheid oor wat die basis, taak en metode van die vak moet wees. Aan Gabler kom die eer toe dat hy aan Ou-Testamentiese Teologie 'n selfstandige plek in die teologie besorg het. Gabler het die vak gesien as ' $n$ historiese wetenskap met ' $n$ deskriptiewe taak. Vir lank is die vraag gevra of die vak net suiwer deskriptief moet en kan wees en of dit nie ook 'n normatiewe taak het nie. Dit was 'n worsteling met die digotomie "what it meant" en "what it means". In die soeke na eie identiteit is hierdie aanvanklike vraag opgevolg deur talle ander vrae.

Hoewel die vak nou al eeue oud is, is Ou-Testamentiese Teologie vandag nog onseker van sy ware identiteit. Hiervan getuig Hasel se uitspraak in die voorwoord tot sy boek: "Old Testament theology today is undeniably in crisis." 1 ) Volgens hom is daar vandag nie eens eenstemmigheid oor die "basic issues" nie. Die titel van Childs se boek Biblical Theology in crisis (1970) gee ook iets weer van hierdie krisissituasie. 
Prinsloo wys tereg daarop dat "alhoewel die situasie in die Ou Testament Teologie as 'n krisis beskou word, dit tegelyk as 'n bloeitydperk getipeer kan word". 2) Hiervan getuig die groot aantal Ou Testament Teologieë wat die afgelope tyd verskyn het. Miskien is dit so dat die krisis juis bygedra het tot buitengewone kreatiwiteit en werksaamheid in die vak. Die jongste van hierdie teologieë is die werk van B S Childs, Old Testament Theology in a canonical context, wat so onlangs as 1985 verskyn het. In my kritiese evaluasie van die kanoniese benadering sal ek op hierdie werk konsentreer.

Die werkmetode sal soos volg wees: Ek gaan in die eerste plek poog om aan die hand van Childs se vier hoofwerke, naamlik Biblical Theology in crisis, Introduction to the Old Testament as Scripture, sy kommentaar op Eksodus en Old Testament Theology in a canonical context te sê wat sy kanoniese benadering behels. Daarna sal ek aan die hand van veral laasgenoemde werk sy benadering krities evalueer.

\section{CHILDS SE KANONIESE BENADERING: WAT GEE AANLEIDING TOT DIE ONTSTAAN VAN HIERDIE BENADERING?}

Die poging in die VSA om ' $n$ brug te slaan tussen die histories-kritiese metode en fundamentalisme het volgens Childs misluk. Dit is duidelik dat Childs teleurgesteld is met die histories-kritiese metode wat volgens hom ' $n$ fragmentasie van die teks teweeggebring het. $\mathrm{Hy}$ bepleit dus ' $\mathrm{n}$ totaal nuwe benadering. "I am now convinced that the relation between the historical critical study of the Bible and its theological use as religious literature within a community of faith and practice needs to be completely rethought. Minor adjustments are not only inadequate, but also conceal the extent of the dry rot." ${ }^{\prime 3)}$ Sy ontevredenheid met die "linkerkant", naamlik die histories-kritiese is net so sterk as sy ontevredenheid met die "regterkant", naamlik die fundamentaliste. Sy voorstel van 'n kanoniese benadering lyk vir my na 'n poging om via die "middelgrond" die Bybelse Teologie uit die doodloopstraat te lei.

Dit gaan vir hom beslis nie om die aanpassing van bestaande metodes nie, maar eerder die daarstelling van iets heeltemal anders en nuuts. "The most pressing need within the contemporary scene seems to be in suggesting a new manner of theological reflection rather than once again rehearsing in detail the familiar lines of earlier research."

Uit sowel sy Inleiding as sy Teologie is dit baie duidelik dat hy ontevrede is met die resultate van die histories-kritiese ondersoek. Ten spyte van al die werk wat gedoen is, bestaan daar volgens hom nog talle probleme wat opgelos moet word. Wat sy Inleiding betref, voel hy dat 
die kritiese inleidings nie as doelwit gehad het die analisering van die kanoniese literatuur nie, maar eerder besig was met die beskrywing van die ontwikkeling van Hebreeuse literatuur en die naspoor van die vroeë en latere stadia van hierdie ontwikkeling. Hy sê verder: "the critical Introduction usually fails to understand the peculiar dynamics of Israel's religious literature". ${ }^{5)}$ Die histories-kritiese Inleiding het nie daarin geslaag om die aard van die literatuur in verband te bring met die gemeenskap wat dit as Heilige Skrif beskou nie.

Ook wat die Teologie betref is daar bestaande probleme wat vra vir "a fresh proposal which can at least begin to point in a direction of overcoming the present impasse". ${ }^{6)}$ Van hierdie probleme is onder andere die fundamentele vraag of die dissipline gesien moet word as ' $n$ teologie van die Ou Testament, of as ' $n$ geskiedenis van Israel se godsdiens, of albei. Dit is verder problematies hoe om literatuur wat bestaan uit so ' $n$ enorme verskeidenheid en wat 'n groeiproses deurloop het van opeenvolgende fases, teologies te hanteer. Die verhouding van $\mathrm{Ou}$ Testament Teologie tot Judaïsme en die Nuwe Testament bly volgens Childs nou nog verwarrend en swak gedefinieer.

Volgens Childs is die wortel van die probleem die probleem van die kanon, "that is to say, how one understands the nature of the Old Testament in relation to its authority for the community of faith and practice which shaped and preserved it" ${ }^{\prime \prime}{ }^{7}$ "Die uitwerking van die geskiedenis op die konsep van die kanon is vir hom duidelik. Enersyds het geleerdes wat die histories-kritiese metode beoefen het nie meer genoegsame plek aan die kanon toegeken nie. Andersyds het geleerdes wat die konsep van die kanon behou nie genoegsame plek aan die historiese kritiek gegee nie. Hierdie polariteit lê aan die hart van die probleem. Die belangrike taak volgens hom is om ' $n$ weg te vind waarlangs hierdie spanning tussen kanon en kritiek opgelos kan word. "Is it possible to understand the Old Testament as canonical scripture and yet to make full and consistent use of the historical critical tools?'"8) As oplossing van die probleem bepleit Childs ' $n$ kanoniese benadering wat nie alleen talle metodologiese probleme sal oplos nie, maar ook weë sal open waardeur die Ou Testament bevry sal word om 'n meer kragtige teologiese rol te speel in die lewe van die kerk.

\section{WAT BEHELS DIE KANONIESE BENADERING?}

Childs stel dit dat die kanoniese benadering tot die Ou Testament as objek van teologiese studie die kanoniese geskrifte van die Ou Testament het. "Canonical analysis focuses its attention on the final form of the text 
itself. It seeks neither to use the text merely as a source for other information obtained by means of an oblique reading, nor to reconstruct a history of religious development." ${ }^{\prime 9)}$ Die kanon van die Christelike kerk is volgens hom die geskikte konteks waarbinne Bybelse Teologie beoefen moet word. Volgens hom moet daar nie gevra word na gebeure of ervarings agter die teks nie. Daar moet veel eerder gekyk word hoe 'n teks gefunksioneer het in die religieuse gemeenskap wat dit erken het as gesaghebbend en normatief. Die tekste word bestudeer as dokumente wat deur geskiedenis en teologie beïnvloed is en het 'n normatiewe funksie gekry in die gemeenskap waar dit gefunksioneer het.

Hierdie benadering wil werk met interpretatiewe strukture wat die Bybelse teks ontvang het van hulle wat dit gevorm en gebruik het as Heilige Skrif. Om hierdie kanoniese vorm te verstaan, vereis volgens Childs die hoogste graad van eksegetiese vaardigheid en intensiewe worsteling met die teks. Om Bybelse Teologie te beoefen binne die konteks van die kanon sluit vir hom die erkenning van die normatiewe kwaliteit van die Bybelse tradisie in. Alleen die kanoniese vorm van die Bybelse teks is vir hom normatief vir Bybelse Teologie.

In veral sy Inleiding maak Childs baie van die "finale vorm van die teks". Die belangrikheid van die finale vorm lê daarin "that it alone bears witness to the full history of revelation". ${ }^{10)}$ Binne die Ou Testament het nòg die proses van vorming van die literatuur nòg die geskiedenis van die kanonisering daarvan ' $n$ onafhanklike integriteit. Slegs in die finale vorm van die Bybelse teks bereik die normatiewe geskiedenis sy eindpunt en kan die voile uitwerking van hierdie openbaringsgeskiedenis gesien word. Hierdie finale vorm het egter ook 'n kritiese funksie ten opsigte van die vroeëre stadia van die vorming van die literatuur. Die doel van die aandrang op die outoriteit van die finale kanoniese vorm is om hierdie kritiese rol te verdedig. Dit wil lyk asof Childs met bogenoemde uitgangspunt mik teen die opvatting van die tradisiegeskiedenis wat openbaring sien as die proses van tradisie-bou. Om die waarheid te sê, hy stel dit duidelik dat die kanoniese benadering onderskei moet word van die tradisie-kritiese benadering. Deur klem te lê op die finale vorm van die teks ontlok dit die sterkste teenkanting van die tradisie-historiese kritiek wat die ontdekking van ' $n$ dieptedimensie sien as die belangrikste taak van die eksegese. "The pre-history or post-history of the text, the precanonical or post-canonical developments, are not decisive as regards the normative value of the Bible as Scripture, even though they are not excluded from consideration."11) Die kanoniese benadering se siening van tradisie staan volgens hom direk teenoor twee uiterste teologiese posisies. Aan die een kant staan dit teenoor die fundamentaliste wat die goddelike inisiatief dermate oorbeklemtoon dat dit die teologiese 
belangrikheid van die reaksie van die volk van God heeltemal ignoreer. Aan die ander kant is dit onversoenbaar met die posisie van die teologies liberales wat die ontstaan van die Bybel sien in suiwer humanistiese terme soos byvoorbeeld Israel se soeke na self-identitiet.

Childs aanvaar dit nie dat na die kanoniese benadering verwys word as "canonical criticism" nie. Dit sou beteken dat die kanoniese benadering gesien word as gewoon nog 'n histories-kritiese tegniek langs byvoorbeeld vormkritiek, bronnekritiek, ensovoorts. Hierdie benadering wil veel eerder 'n posisie daarstel vanwaar die Bybel gelees kan word as Heilige Skrif. Die kanon speel volgens hom sowel 'n negatiewe as ' $n$ positiewe rol in die bepaling van die skopus van die eksegese. Aan die negatiewe kant wil dit die aansprake van prioriteit soos gemaak deur die histories-kritiese metode relativeer. Dit verwerp die veronderstelling dat elke teks eers deur die histories-kritiese proses moet gaan voordat daar begin kan word met die interpretasie. Aan die positiewe kant soek hierdie benadering daarna "to challenge the interpreter to look closely at the biblical text in its received form and then critically discern its function for a community of faith" ${ }^{12)}$ Volgens hom moet die kanoniese vorm nie gesien word as sou dit die betekenis van 'n bepaalde teks bepaal nie. Dit teken eerder die grense waarbinne die eksegetiese taak gedoen moet word. Die kanoniese benadering beperk enersyds die eksegetiese taak daarin dat dit die tradisionele "parameters" ernstig opneem. Andersyds bring hierdie benadering bevryding van die versmorende uitwerking van wat hy noem akademiese skolastisisme. Hy dring daarop aan dat die eksegetiese taak "constructive as well as descriptive"13) is. Die deskriptiewe taak behels die korrekte interpretasie van die antieke teks wat getuienis lewer van die historiese Israel se geloof. Maar die moderne interpreteerder soek ook na 'n boodskap uit die teks en die standpunt wat hy inneem teenoor die teks sal noodwendig die interpretasie beinvloed. Die eksegeet word hierdeur gedwing om hom besig te hou met die gesaghebbende teks van die Skrif in sy voortgaande teologiese arbeid. Deur die kanoniese teks te plaas in die konteks van die gemeenskap van geloof word ' $n$ verskeidenheid van eksegetiese modelle bevry om besig te raak met die teks. "In sum, the canon establishes a platform from which exegesis is launched rather than a barrier by which creative activity is restrained."14)

Hasel wys daarop dat Childs die historiese konteks vir interpretasie verruil vir die kanoniese. Die enigste waarde van byvoorbeeld die analise van die voor-geskiedenis van die teks is daarin geleë dat dit lig werp op die finale teks. Volgens Hasel het Childs dus 'n post-kritiese benadering.

Childs maak 'n onderskeid tussen Bybelse Teologie en Ou- en Nuwe-Testamentiese Teologie. Bybelse Teologie het te doen met albei 
die Testamente. Dit beteken dat die hele Bybelse kanon die konteks vorm van die Bybelse Teologie. Die taak van Bybelse Teologie is dan volgens Childs om die verhouding tussen die twee Testamente te ondersoek. Die Christelike kanon handhaaf die integriteit van die Ou Testament as Skrif van die kerk. Binne 'n nuwe kanoniese konteks word dit geplaas in 'n dialektiese verhouding met die Nuwe Testament. Die taak van Ou-Testamentiese Teologie is om teologies na te dink oor die een deel van die Christelike kanon, maar dit tog altyd te sien as Christelike Skrif. Childs sê: "The task of Old Testament Theology is, therefore, not to Christianize the Old Testament by identifying it with the New Testament witness, but to hear its own theological testimony to the God of Israel whom the church confesses also to worship." 15 )

Childs is verder van mening dat Ou-Testamentiese Teologie nie net ' $n$ beskrywing van ' $n$ historiese proses in die verlede kan wees nie, maar dat dit ook ' $n$ worsteling in die hede is. "Old Testament theology is a continuing enterprise in which each new generation must engage." 16 ) Daar is nie ' $n$ enkele verlore sleutel wat maar net gevind moet word nie; daar bestaan ongelukkig nie een hermeneutiese sleutel wat die Bybelse boodskap kan ontsluit nie. Volgens Childs voorsien die kanon 'n arena waarbinne die worsteling om die verstaan van die Ou Testament kan plaasvind.

\section{'N KRITIESE EVALUASIE VAN DIE KANONIESE BENADERING AAN DIE HAND VAN OLD TESTAMENT THEOLOGY IN A CANONICAL CONTEXT}

Brevard Childs is ongetwyfeld een van die groot persoonlikhede in kontemporêre Ou-Testamentiese studie. James Barr, een van sy skerpste kritici, beskryf hom soos volg: "openminded and imaginative, generous and creative, aware of every side of the subject, international in the scope of his understanding". ${ }^{17)} \mathrm{Hy}$ was een van die invloedrykste Ou-Testamentici, en het daarin geslaag om sy groot geleerdheid te kombineer met ' $n$ diep teologiese begrip; derhalwe kan mens nie anders nie as om te wens, volgens Barr, om aan sy kant te wees nie. Childs se werk het sedert 1970 ' $n$ belangrike rol gespeel in die Ou-Testamentiese Wetenskap; mens wil byna sê die Ou-Testamentiese toneel is daardeur oorheers. Geen persoon se werk is enersyds so aangeprys en andersyds so skerp gekritiseer nie. Die opspraakwekkende Biblical Theology in crisis (1970) word opgevolg met Exodus, A critical, theological commentary (1974). Hierin poog hy om volgens Sanders ${ }^{18)}$ bymekaar te bring wat die vorm- en tradisie-kritiek uitmekaar geskeur het. In 1979 verskyn sy In- 
troduction to the Old Testament as Scripture, 'n werk wat in die meeste gevalle die hoogste lof gekry het. Die volgende uitsprake getuig hiervan: "Introductions to the Old Testament are rarely, if ever, original and exciting. The work of Brevard Childs is both."19) Landes beskryf dit as "much needed, and valuable contribution to the literary category of biblical introduction". ${ }^{20)}$ Rudolf Smend sê: "My expectation was not disappointed. Childs' book is to me the most important new publication of recent years in our discipline."21) Hasel bestempel dié Inleiding as "breathtaking"..22)

Die naam wat Childs vir homself gemaak het deur die werk wat hy gelewer het, het mens laat uitsien na ' $n$ Teologie van die Ou Testament uit sy pen. Dit is tog so dat nadat hy ' $n$ weldeurdagte kommentaar en Inleiding geskryf het, mens sou voel dat ' $n$ Teologie die kroon van sy werk sou wees. In 1985 verskyn Old Testament Theology in a canonical context dan ook.

Dit val dadelik op dat die omvang van die werk, bladsygewys, baie kleiner is as byvoorbeeld sy vorige werke. Die volume dek ' $n$ ontsaglike groot veld in, proporsioneel gesproke, 'n klein hoeveelheid bladsye. In 20 hoofstukke behandel Childs baie belangrike terreine van die Teologie. Die boek is nie opgedeel in groter eenhede nie, maar dit lyk tog asof mens rofweg die hoofstukke onder die volgende hoofde sal kan indeel. Hoofstukke 1-4, Die Openbaring; Hoofstukke 5-8, Wet en Dekaloog; Hoofstukke 9-14, Ontvangers en agente van die Openbaring; Hoofstukke 15-18, Die gewone menslike lewe; Hoofstuk 19, Lewe bedreig (sonde); Hoofstuk 20, Lewe onder die belofte (eskatologie). Walter Brueggemann onderskei in dié boek vier hoofafdelings, naamlik " $(1)$ the mode and substance of revelation (2) the ethical claims of the canon (3) the offices of Israel, judge, king, prophet, priest and (4) the organizational life of Israel". ${ }^{23}$ ) Die bondige hantering van belangrike temas deur Childs val dadelik op. Soms kom dit telegramagtig voor, en dit het ' $n$ skadelike uitwerking op die gehalte van die werk. Hunt ${ }^{24)}$ konkludeer soos volg: "One might suspect that having gone over the material so many times already Childs might have become somewhat tired of all the details."

In die lig van die geweldige invloed van Childs op die OuTestamentiese wetenskap, die gehalte van sy werk in die verlede en die belofte wat sy arbeid inhou, kan mens nie anders nie as om te sê dat sy nuutste werk ietwat raaiselagtig voorkom en 'n groot teleurstelling is. "Perhaps, if it were not authored by Childs, the disappointment would not be so keen, because the expectation would not be so high." ${ }^{25)}$ Wat gou duidelik word is die feit dat die boek ' $n$ sterk polemiese karakter het met opponente aan sowel die linker- as die regterkant van die teologiese 
spektrum. Von Rad, Zimmerli en ook Eichrodt is onder andere sy vernaamste gespreksgenote. Die gesprek sentreer hoofsaaklik om temas wat ander Ou-Testament Teologieë reeds gedek het. Dit was vir my taamlik onbevredigend dat die standpunte van die persone wat hy gekritiseer en verwerp het nie moeilik was om te identifiseer nie terwyl sy eie standpunt eerder voorop kom staan het. Sy gebruik van tekste is baie selektief, maar die redes vir sy seleksies is ongelukkig nie altyd duidelik nie. Dwarsdeur die boek kry mens die indruk dat Childs wil impliseer dat niemand anders voorheen reg was nie, maar dat die kanoniese benadering alleen die antwoord het. Miskien is dit wat Sanders ${ }^{26)}$ in 1980 gesê het, naamlik dat Childs se benadering 'n oorreaksie is teen die historieskritiese metode, ook hier van toepassing. Mens moet dit seker beoordeel in die lig daarvan dat hyself verklaar het dat hy nie net besig is met 'n nuwe metode nie, maar dat sy benadering 'n radikale wegbreek is van die tradisionele historiese eksegese.

Die skerpste kritiek wat mens kan uitspreek, hang saam met die feit dat juis Childs die struktuur van die kanon in hierdie werk van hom nie ernstig opneem nie. "Childs' book is enigmatic, because he does not seem to adhere stringently to the notion of canon, which he himself has articulated."27) Childs self sê: "The canonical process involved the shaping of the tradition not only into independent books, but also into larger canonical units such as the Torah, Prophets and Writings."28) Hy werk skynbaar verkieslik in sy Teologie met die "larger canonical units". Tog dink ek Rodd se uitspraak is geregverdig as hy sê: "Yet in the end we still wonder what makes this a canonical theology. Why has the structure of the canon, either in its Hebrew or Christian form, played such an indecisive part in the presentation?'29) Hoewel Childs voortdurend hamer op die "canonical shape", kom daar maar min van 'n kanoniese benadering in sy boek tot sy reg. Die besware wat Barr in 1980 ná die verskyning van Childs se Inleiding geopper het oor die hantering van die begrip "kanon" geld ongelukkig nog in 'n groot mate ook ten opsigte van sy Teologie. Barr het destyds gesê wat ons vandag weer moet sê: "Canon in this book is vaguely and unanalytically treated." ${ }^{30}$ )

Prinsloo ${ }^{31}$ ) wys daarop dat Childs se rigiede fokus op die kanon nie genoeg ruimte laat vir die dinamiese proses wat die teks voorafgegaan het nie. Sy opvatting dat die kanoniese konteks die oorspronklike historiese konteks ophef, laat mens wonder of hy hom nie laat lei deur'n a-historiese en dogmatiese beginsel nie. Vroeër het ek daarop gewys dat Childs met sy benadering poog om ' $n$ brug te slaan tussen die historieskritiese en 'n meer teologiese benadering. Dit wil tog vir my lyk asof hy nie daarin slaag om die twee te integreer nie.

Childs se hantering van die verhouding Ou Testament-Nuwe Testa- 
ment is ietwat problematies. In sy Eksodus-kommentaar gee hy erkenning vir die feit dat die Nuwe Testament die Ou Testament op 'n verskeidenheid van maniere gebruik. Die eksegese van die Nuwe Testament is wat sowel vorm as inhoud betref beinvloed deur die Hellenistiese omgewing. "Dit is eksegeties onverantwoord om die NuweTestamentiese 'aanhalings' van die Ou Testament as kriterium te gebruik om die Ou-Testament gedeeltes mee te interpreteer." ${ }^{\text {"32) }}$ Die Ou Testament het tog sy eie betekenis en mens moet soek om dit ook te verstaan sonder om hierdie oorspronklike betekenis op te offer ter wille van die kanoniese konteks. Die verhouding Ou-Testamentiese Teologie en Nuwe-Testamentiese Teologie teenoor Bybelse Teologie soos Childs dit sien, veroorsaak ook probleme. Hase ${ }^{33}$ ) wys daarop dat die metodologiese wig wat Childs ingedryf het tussen sy "new Biblical theology" en die Ou-Testamentiese/Nuwe-Testamentiese Teologie kunsmatig is. Hy sien die Bybelse Teologie as gegrond in die totale Bybelse kanon, en ook normatief van aard. "Childs drives a wedge between Biblical theology, which is normative and theological, and O.T. theology (and N.T. theology) which is historical and non-normative. ${ }^{\prime 34}$ ) As mens Ou-Testamentiese Teologie so sien dan is daar nie eintlik meer sprake van Ou-Testamentiese Teologie nie; dan is dit nie veel meer as ' $n$ geskiedenis van die godsdiens van Israel nie, aldus Hasel.

Al die kritiek wat uitgespreek is kan die feit nie verander dat Childs 'n geweldige bydrae gelewer het tot die Ou-Testamentiese wetenskap nie. "Sy grootste bydrae lê daarin dat hy tereg gewys het op die belangrikheid van die finale vorm van die teks." ${ }^{\text {35) }}$ Sy voorstelle is in 'n groot mate 'n reaksie teen die histories-kritiese metode. Hierdie metode het met sy klem op die voor-geskiedenis van die teks gelei tot ' $n$ fragmentasie van die teks. Stuhlmacher verwys na die histories-kritiese metode as dié metode "which has made of the biblical canon such a ruinous heap of hypothetical possibilities". ${ }^{36)}$ Childs se aandrang op "the normative status of the final form of the text" ${ }^{\prime 37}$, , moet in die lig van bogenoemde waardeer word. Ten spyte van die feit dat hy beskuldig word dat hy werk met "an unacceptable myth of canon"38) lyk sy aandrang dat die ware konteks van die teologie die kanon is, en nie die een of ander kriterium buite die kanon of ' $n$ kanon binne die kanon nie, vir my na 'n winspunt.

Eksegese is vir Childs nie 'n objektiewe, deskriptiewe saak nie, maar iets wat binne die geloofsraamwerk plaasvind. Dit lyk vir my asoif hy dit nie as 'n wetenskap ter wille van wetenskap sien nie. Hy sien eksegese eerder as iets wat in diens van die geloofsgemeenskap staan. In dié opsig is hy dit eens met Mildenberger wat sê: "biblical exegesis - for progmatic reasons divided into the Old and New Testament disciplines, 
but from the viewpoint of the canon to be seen as a unity - has the task of uncovering the original witness of the Old and New Testaments for use in the church". 39 )

Prinsloo ${ }^{40)}$ prys Childs se poging aan om tot 'n meer teologiese benadering te kom en om te midde van die grooit diversiteit van die Bybel, dit tot ' $n$ eenheid aan te wend. Hoewel daar hier en daar ligpunte is in sy jongste werk moet ek tog saamstem met Brueggemann ${ }^{41)}$ dat die boek ' $n$ teleurstelling is. Mens het gehoop dat Childs dié persoon is wat 'n nuwe benadering tot die Ou-Tetamentiese Teologie kan inlei. Ongelukkig lyk dit asof die boek tog maar in 'n groot mate ' $n$ herhaling is van wat reeds gesê is. Mens moet egter toegee dat dit wel soms met 'n ander nuanse gesê is.

Uit dit wat hierbo gesê is moet mens tot die slotsom kom dat Childs in sy Teologie hom nie hou by die grondreëls wat hy self neergelê het nie. "I do not believe this book advances the discussion of canonical modes of interpretation." "42) In die lig van die werk wat Childs in die verlede gelewer het, is meer van hom verwag. Mens kan maar net hoop dat Childs miskien nog ' $n$ boek beplan waarin hy duideliker sal illustreer hoe 'n Teologie geskryf moet word volgens die kanoniese benadering.

\section{NOTAS}

1. G F Hasel, Old Testament Theology: Basic issues in the current debate, Grand Rapids 1982, 9.

2. W S Prinsloo, "Ou Testament Teologie vandag", in Ou Testament Teologie: Gister, vandag en mb́re. Pretoria 1987, 30.

3. B S Childs, Introduction to the O/d Testament as Scripture, London 1979, 15.

4. B S Childs, Old Testament Theology in a canonical context, London 1985, xii.

5. Childs, aw, 1979, 40.

6. Childs, aw, $1985,5$.

7. Childs, aw, 1979, 41.

8. Childs, aw, 1979, 45.

9. Childs, aw, 1979, 73.

10. Childs, aw, 1979, 76.

11. Hasel, aw, 90.

12. Childs, aw, 1979, 83.

13. Childs, aw, 1979, 83.

14. Childs, aw, 1979, 83.

15. Childs, aw, 1985, 9.

16. Childs, aw, 1985, 12.

17. J Barr, "Childs' Introduction to the Old Testament as Scripture", Journal for the Study of the O/d Testament 16 (1980), 12-23.

18. J A Sanders, "Canonical context and canonical criticism", Horizons in Bib/ical Theologr 2 (1980), 173-197.

19. R E Murphy, "The Old Testament as Scripture", Journal for the Study of the Old Testament 16 (1980), 40-44. 
20. G M Landes, "The canonical approach to introducing the Old Testament: Prodigy and problems", Journal for the Study of the Old Testament 16 (1980), 32-39.

21. R Smend, "Questions about the importance of the canon in an Old Testament introduction", Journal for the Study of the Old Testament 16 (1980), 45-51.

23. W Brueggemann, "Old Testament Theology in a canonical context by Brevard S Childs", Theology Today vol XLIII (1986), 284-287.

24. J I Hunt, "Brevard S Childs' Old Testament Theology in a canonical context", Biblical Theology Bulletin vol XVII (1987), 31.

25. Brueggemann, Theology Today vol XLIII (1986), 284-287.

26. Sanders, Horizons in Biblical Theology $2(1980), 173-197$.

27. Brueggemann, Theology Today vol XLIII (1986), 284-287.

28. Childs, aw, 1985, 13

29. C S Rodd, "Talking points from books", The Expository Times 97/8 (1986), $226-227$.

30. J Barr, Journal for the Study of the Old Testament 16 (1980), 12-23.

31. Prinsloo, aw, 37.

32. Prinsloo, aw, 37.

33. Hasel, aw, 91 .

34. Hasel, aw, 92.

35. Prinsloo, aw, 36.

36. P Stuhlmacher, Historical criticism and theological interpretation of Scripture, Philadelphia 1977, 75.

37. Hasel, aw, 90.

38. S E McEvenue, "The Old Testament, Scripture or Theology", Interpretation 35/1 (1981), 229-242.

39. Stuhlmacher, aw, 79.

40. Prinsloo, aw, 36 .

41. Brueggemann, Theology Today vol XLIII (1986), 284-287.

42. Ibid.

\section{Addisionele bibliografie}

J Blenkinsopp, "A new kind of Introduction: Professor Childs' Introduction to the Old Testament as Scripture", Journal for the Study of the O/d Testament 16 (1980), $24-27$.

H Cazelles, "The canonical approach to Torah and Prophets", Journal for the Study of the Old Testament 16 (1980), 28-31.

B S Childs, Exodus, London 1974.

B S Childs, "Response to Reviewers of Introduction to the Old Testament as Scripture", Journal for the Study of the Old Testament 16 (1980), 52-60.

B Kittel, "Brevard Childs' Development of Canonical Approach", Journal for the Study of the Old Testament 16 (1980), 2-11.

P D Miller, "Biblical Theology in crisis, by B S Schilds", Journal of Biblical Literature 22 (1971), 209-210.

J D Smart, The Past, present and future of Biblical Theology, Philadelphia 1979. 